\title{
REVIEW
}

\section{The raptors of Torres del Paine National Park, Chile: biodiversity and conservation}

\author{
Las rapaces del Parque Nacional Torres del Paine, Chile: biodiversidad y \\ conservación
}

\begin{abstract}
FABIAN M. JAKSIC ${ }^{1}$, J. AGUSTÍN IRIARTE² \& JAIME E. JIMÉNEZ ${ }^{3}$
${ }^{1}$ Center for Advanced Studies in Ecology \& Biodiversity, Pontificia Universidad Católica de Chile, Casilla 114-D, Santiago, Chile; fjaksic@genes.bio.puc.cl

${ }^{2}$ Departamento de Protección de Recursos Naturales Renovables, Servicio Agrícola y Ganadero, Avenida Bulnes 140, Santiago, Chile

${ }^{3}$ Laboratorio de Ecología, Universidad de Los Lagos, Casilla 933, Osorno, Chile
\end{abstract}

\begin{abstract}
Fifteen raptor species (Falconiformes and Strigiformes) breed and other two may breed in Torres del Paine National Park (Chilean Patagonia), the highest raptor species richness documented in Chile. Accounts for each raptor species in Torres del Paine are provided, including information on weight, habitat, diet, residence, conservation, and miscellaneous observations in the Park. We compare raptor species richness in Torres del Paine with well studied localities in central and northern Chile, and speculate on causes for the higher raptor diversity observed in the Park. Raptor macroniches in Torres del Paine are assessed, describing primarily their use of two major habitat types and nine food resources. We examine food-niche relationships for a subset of four mammal-eating raptors, in light of their different ecologies and body sizes. A monitoring program for raptors in Torres del Paine is proposed, under the rationale that these indicator species may help foresee impending disruptions of basic ecosystem processes that determine the relatively pristine conditions still prevailing in the Park.
\end{abstract}

Key words: Falconiformes, Strigiformes, Chile, Patagonia, diet, weight, habitat use, niche relationships.

\section{RESUMEN}

Quince especies de rapaces (Falconiformes y Strigiformes) se reproducen y otras dos posiblemente se reproducen en el Parque Nacional Torres del Paine (Patagonia chilena), la mayor riqueza de especies de rapaces documentada hasta ahora en Chile. Entregamos descripciones de cada especie de rapaz en Torres del Paine, incluyendo información sobre peso, hábitat, dieta, residencia, conservación, y observaciones misceláneas en el Parque. Comparamos la riqueza de especies de rapaces en Torres del Paine con aquella en localidades bien estudiadas del centro y norte de Chile, y especulamos sobre las causas de la mayor diversidad de rapaces observadas en el Parque. Determinamos los macronichos de las rapaces en Torres del Paine, describiendo principalmente su uso de dos tipos de hábitats predominantes y de nueve tipos de recursos alimentarios. Examinamos las relaciones de nicho trófico en un conjunto de cuatro rapaces consumidoras de micromamíferos, a la luz de sus diferentes ecologías y tamaños corporales. Esbozamos un programa de monitoreo para las rapaces de Torres del Paine, bajo el criterio que estas especies indicadoras pueden ayudar a prever posibles disfunciones de los procesos ecosistémicos básicos que determinan las condiciones relativamente prístinas aún prevalentes en el Parque.

Palabras clave: Falconiformes, Strigiformes, Chile, Patagonia, dieta, peso, uso del hábitat, relaciones de nicho.

\section{INTRODUCTION}

Raptors are at the end of a series of energy transfers along food chains, from the primary producers up to several organisms that prey on each other. Being a top predator does not guarantee an easy existence. The likelihood that raptors will become prey of other predators is low, but their prey is not easy to catch. Those that are easily caught may be weakened by parasites, diseases, and toxins that may in turn decrease the raptors' fitness (that is, their survival compounded by reproductive success). Raptors are indeed a sink into which all ailments of an ecosystem pour, sooner or later. If poison is applied to control "vermin species," such as rabbits or hares, it may be ingested and may eventually kill a raptor that was contributing to keeping the vermin's population in check, thus 
only fueling more massive poisoning campaigns into a never-ending spiral. Insecticides such as Dichloro Diphenyl Tricloroethane (DDT) are still ilegally used in Chile to control insect pests in agricultural areas. After a short transit through insectivorous birds or small mammals these dangerous insecticides become concentrated in raptor tissues (Mendelhall \& Pank 1980, Townsend et al. 1981), thus altering the fragile predator-prey equilibrium. Even lead used for shooting game birds quickly migrates through the food chain up to raptors. Thus, raptors are valuable and sensitive indicators of an ecosystem's health.

Because raptors are large and conspicuous (at least, the diurnal ones), it is relatively easy to measure their abundance and reproductive success, thus providing early warnings about deteriorating processes that may be affecting the ecosystem. But in order for raptors to become a precise environmental gauge, a full understanding must be gained of their interactions with their prey and among themselves. This begins by assessing when and where in a particular site they occur, what they eat, and how they interact. Torres del Paine National Park in southernmost Chile, offers a unique opportunity to use raptors as environmental indicators because it is a relatively pristine area. Our aim in this paper, apart from bringing together what is known about the Park's raptors, is to set a baseline, so that future changes may be gauged in a monitoring program yet to be started.

\section{MATERIAL AND METHODS}

This paper is based on a review of the relevant literature on Torres del Paine National Park, and on our collective experience. Major literature sources consulted were: Pisano (1974), for vegetation characteristics of the Park; Humphrey et al. (1970) and C. Venegas (personal communication), for raptor weights; Johnson (1965, 1967), Markham (1971), Venegas \& Jory (1979), and Venegas (1982), for raptor distributions; Humphrey et al. (1970) and Vuilleumier (1985), for raptor habitats and residence status; Jaksic \& Jiménez (1986a), for raptor conservation status; many sources clearly identifiable by their titles in the bibliography section, for raptor diets; and Iriarte et al. (1990), for raptor niche relationships. It should be noted that our own field experience sometimes contradicts the literature sources consulted.

We recognize three major habitat types used by raptors, but only two of these stand from a botanical viewpoint: Forest includes the Park's dense deciduous forests dominated by Nothofagus antarctica and $N$. pumilio (which represent less than $20 \%$ of the surface area of the Park; Iriarte et al. 1990). Open country is composed of both dwarf shrublands dominated by Mulinum spinosum and Verbena tridens, and grasslands dominated by Festuca spp. and Anarthrophyllum patagonicum. Open country comprises about $80 \%$ of the Park's surface (Iriarte et al. 1990). The third habitat type important for raptors is woodlands, which we define as an open-canopy successional forest with a scrub understory, an ecotone between the two major vegetation formations already described. A fourth habitat type might have been considered: cliffs, but surely they are not used as hunting areas by raptors but rather as nesting and roosting sites.

We placed resident raptors in three categories: year-round residents, which breed and overwinter in the Park; breeding migrants, which breed in the Park but migrate out of the area to winter in milder regions; and partial migrants, which breed in the Park, but on arrival of winter conditions may migrate out or stay put (i.e., part of the population leaves and another part remains). It was not always easy to classify raptors into one or the other of these three categories. Those labeled "likely" are based on little more than educated guesses. We have used a few abbreviations for descriptions of gender and age of raptors: $M$ (male), F (female), U (unsexed), A (adult), and I (immature). Unless otherwise stated, all records and observations are from the Park itself or from the Magallanes Region, where the Park is placed.

Finally, vertebrate nomenclature follows Veloso \& Navarro (1988) for amphibians, Núñez \& Jaksic (1992) for reptiles, Del Hoyo et al. (1994, 1999) for raptorial birds, Araya et al. (1995) for nonraptorial birds, and Tamayo et al. (1987) for mammals.

\section{RAPTOR SPECIES ACCOUNTS}

\section{Andean condor (Vultur gryphus Linnaeus 1758, Cathartidae)}

Weight: F 7,500 g (C. Venegas, personal communication). Habitat: cliffs. Diet: obviously the condor is a scavenger of relatively large mammals, and may attack newborn sheep during the lambing season. We once baited condors with a dead sheep for filming purposes and 17 birds arrived. William L. Franklin's film "The Guanaco in Patagonia" shows a condor feeding on a newborn guanaco. J. Behl (personal communication) has seen condors feeding on guanaco carcasses on at least six occasions. Residence: confirmed yearround resident (see also Couve \& Vidal 1999, 
Matus \& Barría 1999, Sarno et al. 2000). Conservation Status in Magallanes region: unknown. Conservation Status in Chile: vulnerable according to both Glade (1988) and Rottmann \& LópezCallejas (1992).

Bicolored hawk (Accipiter bicolor Vieillot 1817, Accipitridae)

Weight: IM 227 g, IF 383 g, AU 425 g (Humphrey et al. 1970); F 275 g, F 370 g, F 414 g, F 415 (C. Venegas personal communication). Habitat: forest (sometimes woodland), in flat or rolling terrain. Diet: Humphrey et al. (1970) reported two prey species from Tierra del Fuego: thorn-tailed rayadito (Aphrastura spinicauda Gmelin 1789) and eared dove (Zenaida auriculata des Murs 1847). Residence: likely breeding migrant; C. Venegas (personal communication) is of the opinion that this species is, at best, occasional, but Couve \& Vidal (1999) and Matus \& Barría (1999) consider it as a year-round resident. Other observations: we have not seen this accipiter, but its presence might be expected on account of its geographic distribution and habitat selection. Conservation Status in Magallanes region: threatened by reduction of its preferred habitat for breeding and feeding (oldgrowth forests), and by shooting (Jaksic \& Jiménez 1986a). Conservation Status in Chile: rare according to both Glade (1988) and Rottmann \& LópezCallejas (1992).

Black-chested eagle (Geranoaetus melanoleucus Vieillot 1819, Accipitridae)

Weight: AM 2,698 g, AF 3,033 g, AF 2,381 g (Humphrey et al. 1970); M 2,300 g, M 2,315 g, F 2,225 g, F 3,025 g (C. Venegas personal communication). Habitat: ecotone between forest and open country, in flat, rolling, or rugged terrain (Jiménez \& Jaksic 1989, 1990). Diet: Iriarte et al. (1990) found that $91 \%$ of prey were European hares (Lepus europaeus Linnaeus 1758), $6 \%$ other mammals, and $3 \%$ birds. Jiménez \& Jaksic (1990) reported $82 \%$ European hares and $18 \%$ birds. Humphrey et al. (1970) reported goslings (Chloephaga sp.) as prey in Tierra del Fuego. Residence: confirmed year-round resident (see also Couve \& Vidal 1999, Matus \& Barría 1999). Other observations: Iriarte et al. (1990) reported five nests on top of tall Nothofagus sp. in the northern part of the Park. Jiménez \& Jaksic (1990) reported 13 nests on cliffs near Administración, Portería, Laguna Amarga, and Laguna de los Cisnes. Conservation Status in Magallanes: of no conservation concern at present, because prey availability has increased due to the introduction in 1896 , and subsequent population irruption of the European hare (Grigera \& Rapoport 1983), and to increased edge habitat between forest and open country caused by forest clearing (Jaksic \& Jiménez 1986a). Conservation Status in Chile: not listed as threatened by either Glade (1988) or by Rottmann \& López-Callejas (1992).

\section{Red-backed hawk (Buteo polyosoma Quoy \& Gaimard 1824, Accipitridae)}

Weight: AM 1,134 g, AM 1,134 g, AM 992 g, IF 1,417 g (Humphrey et al. 1970); M 856 g, M 950 g, M 1,105 g, M 1,258 g, F 1,265 g, F 1,372 g (C. Venegas, personal communication). Habitat: ecotone between forest and open country, in flat, rolling, or rugged terrain (Jiménez 1995). Diet: Humphrey et al. (1970) reported Ctenomys magellanicus Bennett 1835 (Magellan tuco-tuco) as prey in Tierra del Fuego. Residence: confirmed partial migrant. Couve \& Vidal (1999) consider it as an infrequent visitor to the Park, whereas Matus \& Barría (1999) consider it a year-round resident. Other observations: we have seen this buteo on few occasions only, near Portería; once we saw an individual chased by a black-chested eagle. Conservation Status in Magallanes: threatened by reduction of presumable staple prey (Magellan tuco-tuco), caused by sheep trampling this fossorial rodent's burrows (Jaksic \& Jiménez 1986a). However, F. Vuilleumier (personal communication) does not believe this to be the case in Tierra del Fuego. Conservation Status in Chile: not listed as threatened by either Glade (1988) or by Rottmann \& López-Callejas (1992).

\section{Rufous-tailed hawk (Buteo ventralis Gould 1837, Accipitridae)}

Weight: M 1,031 g, M 1,175 g, F 1,195 g, F 1,410 g, U 1,735 g (C. Venegas, personal communication). Habitat: probably in forest and ecotone with open country, in flat or rolling terrain. Diet: Humphrey et al. (1970) reported an unidentified rodent as prey in Tierra del Fuego. One of us (J. Jiménez) has seen this species hunting for Chilean pigeon (Columba araucana Lesson 1827) near Valdivia and preying on birds and mammals in Temuco. Residence: likely year-round resident (in line with Matus \& Barría 1999). Nevertheless, Couve \& Vidal (1999) do not list this species as present in the Park. Other observations: we have not seen this buteo, but its presence might be 
expected on account of its geographic distribution and habitat selection. Garay \& Guineo (1993) published a picture supposedly of this hawk from the Park, but in fact it corresponds to a juvenile black-chested eagle (Vuilleumier 1997: 211). According to F. Vuilleumier (personal communication) this species is definitely rare in Magallanes. Conservation Status in Magallanes: unknown (Jaksic \& Jiménez 1986a). Conservation Status in Chile: rare according to both Glade (1988) and Rottmann \& López-Callejas (1992).

Cinereous harrier (Circus cinereus Vieillot 1816, Accipitridae)

Weight: AM 354 g, AF 482 g, IM 340 g (Humphrey et al. 1970); AM 320 g, AF 510 g (Jiménez \& Jaksic 1988); M 315 g, M 359 g, F 427 g, F 475 g (C. Venegas personal communication). Habitat: open country near marshes, in flat or rolling terrain. Diet: Jiménez \& Jaksic (1988) documented its diet as consisting of $19 \%$ mammals, $27 \%$ birds, $19 \%$ reptiles, and $35 \%$ arthropods. Humphrey et al. (1970) reported unidentified rodents and "green lizards" (most likely, Liolaemus magellanicus Hombron \& Jacquinot 1847) as prey in Tierra del Fuego. Residence: confirmed migrant (either breeding migrant or partial migrant). Similarly, Couve \& Vidal (1999) consider it as a summer visitor that breeds in the Park, but Matus \& Barría (1999) consider it as a likely resident. Thus, the residence status of this harrier requires further study. Other observations: abundant only around the small lagoons close to the Portería (where it nests), and less frequently between Portería and Laguna de los Cisnes. Conservation Status in Magallanes: of no conservation concern at present, because the apparent reduction in one of its staple prey, the lizard L. magellanicus (see Jaksic \& Schwenk 1983 ) has been compensated by increased habitat availability (and hence also increased prey) brought about by the clearing of forests (Jaksic \& Jiménez 1986a). Conservation Status in Chile: not listed as threatened by either Glade (1988) or by Rottmann \& López-Callejas (1992).

Chimango caracara (Milvago chimango Vieillot 1816, Falconidae)

Weight: AF 482 g (Humphrey et al. 1970); M 356 g, M 357 g, M 375 g, M 380 g, M 395 g, F 355 g, F 365 g, F 390 g, F 400 g, U 295 g (C. Venegas personal communication). Habitat: open country, in flat or rolling terrain. Diet: Humphrey et al.
(1970) reported that on Tierra del Fuego this caracara is a scavenger but occasionally eats insects. Residence: confirmed breeding migrant. Nevertheless, Couve \& Vidal (1999) and Matus \& Barría (1999) consider it as a year-round resident. Other observations: not abundant, seen most frequently near Portería; one pair was seen nesting in the marsh nearby, among harriers (Circus cinereus). Conservation Status in Magallanes: of no conservation concern at present (Jaksic \& Jiménez 1986a). Conservation Status in Chile: not listed as threatened by either Glade (1988) or by Rottmann \& López-Callejas (1992).

White-throated caracara (Phalcoboenus albogularis Gould 1837, Falconidae)

Weight: AM 808 g, IU 765 g (Humphrey et al. 1970). Habitat: forest and woodland, in flat, rolling, or rugged terrain. Diet: this raptor is likely a scavenger. Residence: likely year-round resident (see also Matus \& Barría 1999). Our assessment differs from that of $\mathrm{C}$. Venegas (personal communication), who opines that this species is only occasional, and that of Couve \& Vidal (1999) who consider it as an yearly visitor to the Park (breeding migrant?). Other observations: not abundant. One of us (J. Jiménez) once saw one of these caracaras scavenging on a sheep in a grassland. Conservation Status in Magallanes: unknown (Jaksic \& Jiménez 1986a). Conservation Status in Chile: not listed as threatened by either Glade (1988) or by Rottmann \& López-Callejas (1992). But according to F. Vuilleumier (personal communication) this species is probably threatened, as is rare in Magallanes (including Tierra del Fuego and Navarino areas).

Crested caracara (Polyborus plancus Miller 1777, Falconidae)

Weight: AM 1,460 g (Humphrey et al. 1970); M 1,266 g, M 1,340 g, F 1,295 g, F 1,340 g, F 1,350 $\mathrm{g}, \mathrm{F} 1,385 \mathrm{~g}$ (C. Venegas personal communication). Habitat: open country, in flat or rolling terrain. Diet: Humphrey et al. (1970) reported that on Tierra del Fuego it is a scavenger, that they saw one caracara eating a goose egg (Chloephaga sp.), and that they found a roosting place with an accumulation of bones of Magellan tuco-tucos (Ctenomys magellanicus). In Torres del Paine crested caracaras scavenge mainly on guanacos and European hares (Engh et al. 1997). J. Behl (personal communication) has seen them feeding on guanaco carcasses and preying on 
hatchlings of lesser rhea (Pterocnemia pennata d'Orbigny 1834). Residence: confirmed yearround resident (see also Couve \& Vidal 1999, Matus \& Barría 1999). Other observations: common in open habitats, particularly between Lago Sarmiento and Lago Nordenskjold. This caracara congregates in large numbers (20-30 individuals) at carcasses. We have seen it scavenge on European hares killed by motor vehicles on Park roads. We saw nests of this species on top of Nothofagus antarctica (ñirre) 4-5 m tall, near water. Conservation Status in Magallanes: of no conservation concern at present, despite being heavily hunted, because of increased food availability (carcasses) caused by roadkills of the abundant European hare, and by poorly managed sheep operations (Jaksic \& Jiménez 1986a). Conservation Status in Chile: not listed as threatened by either Glade (1988) or by Rottmann \& López-Callejas (1992).

Peregrine falcon (Falco peregrinus Tunstall 1771, Falconidae)

Weight: AF 1,035 g, AU 1,049 g (Humphrey et al. 1970); F 995 g, F 1,005 g, F 1, 160 g, F 1, 185 g (C. Venegas personal communication). Habitat: open country, in flat or rolling terrain. Diet: McNutt (1981) reported over 20 bird species as prey elsewhere in Magallanes. Residence: likely partial migrant; C. Venegas (personal communication) is of the opinion that this species is, at best, occasional, but Couve \& Vidal (1999) and Matus \& Barría (1999) consider it as a year-round resident. Other observations: one of us (J. Jiménez) has seen this falcon only once, at Sierra del Toro, and surprisingly it was a pallid, or "kreyenborgi" morph (see Ellis \& Péres-Garat 1983, McNutt 1984). Garay \& Guineo (1993) published a picture supposedly of this falcon from the Park, but in fact it corresponds to a juvenile cinereous harrier (Vuilleumier 1997: 211). McNutt (1981) described the hunting behavior of the falcon in Tierra del Fuego. Conservation Status in Magallanes: unknown (Jaksic \& Jiménez 1986a). According to F. Vuilleumier (personal communication) it is not common, and surely at risk. Conservation Status in Chile: vulnerable according to both Glade (1988) and Rottmann \& LópezCallejas (1992).

Aplomado falcon (Falco femoralis Temminck 1822, Falconidae)

Weight: No data available. Habitat: open country, in flat or rolling terrain. Diet: Humphrey et al.
(1970) reported an unidentified bird as prey in Tierra del Fuego. It is likely that it preys mainly on birds and insects, as reported in central Chile (Jiménez 1993). Residence: likely breeding migrant. Our assessment should be taken cautiously because two other authorities (C. Venegas, F. Vuilleumier) differ in their opinion: for the former, this species is a likely breeding migrant; for the latter, it is merely accidental. Couve \& Vidal (1999) and Matus \& Barría (1999) do not list this species as present in the Park. Other observations: we have not seen this falcon, but $F$. Vuilleumier (personal communication) saw one adult bird near the Park on 26 February 1988. Conservation Status in Magallanes: unknown (Jaksic \& Jiménez 1986a). Conservation Status in Chile: not listed as threatened by Glade (1988), but considered Insufficiently known by Rottmann \& López-Callejas (1992).

\section{American kestrel (Falco sparverius Linnaeus 1758, Falconidae)}

Weight: AM 156 g, AF 142 g (Humphrey et al. 1970); M 130 g, F 140 g, F 154 g, F 155 g, F 163 (C. Venegas personal communication). Habitat: open country, in flat or rolling terrain. Diet: Humphrey et al. (1970) reported that in Tierra del Fuego it preys on small birds, including house wrens (Troglodytes aedon Vieillot 1809), lizards (likely, Liolaemus magellanicus), beetles (Coleoptera), and midges (Diptera). Residence: likely breeding migrant. Couve \& Vidal (1999) and Matus \& Barría (1999) consider it as a year-round resident. Other observations: we have not seen this small falcon, but J. Behl (personal communication) has confirmed sightings and photos of this bird in the Park. McNutt (1984) described the breeding behavior of this falcon in Tierra del Fuego. Conservation Status in Magallanes: of no conservation concern at present. Conservation Status in Chile: not listed as threatened by either Glade (1988) or by Rottmann \& López-Callejas (1992).

Common barn owl (Tyto alba Scopoli 1769, Tytonidae)

Weight: M 259 g, M 383 g (sic), F 295 g, F 305 g, F $310 \mathrm{~g}$ (C. Venegas personal communication). Habitat: open country, in flat or rolling terrain. Diet: Iriarte et al. (1990) reported that its diet is made up entirely of rodents. Humphrey et al. (1970) reported beetles (Coleoptera) and mice (Rodentia) as prey in Tierra del Fuego. Residence: likely 
year-round resident or at least breeding migrant. Couve \& Vidal (1999) consider it as a year-round resident, and Matus \& Barría (1999) consider it as a likely resident. Other observations: we saw nests of two pairs on cliffs near Laguna Amarga. Conservation Status in Magallanes: unknown (Jaksic \& Jiménez 1986a). Conservation Status in Chile: not listed as threatened by either Glade (1988) or by Rottmann \& López-Callejas (1992).

Magellan horned owl (Bubo magellanicus Gmelin 1788 , previously known as Bubo virginianus Gmelin 1788, Strigidae)

Weight: M 940 g, M 1,074 g, F 1,335 g, U 1,015 g (C. Venegas personal communication). Habitat: ecotone between forest and open country, in flat, rolling, or rugged terrain. Diet: quantitative information has been reported by Jaksic et al. (1978), Rau et al. (1978), Yáñez et al. (1978) and Rau \& Yáñez (1981). Jaksic et al. (1986) summarized these reports as follows: $1 \%$ European hares, $87 \%$ rodents, $2 \%$ birds, and $10 \%$ insects. In contrast, Iriarte et al. (1990) found that diet was comprised of $17 \%$ European hares, $79 \%$ rodents, and $4 \%$ birds. The discrepancy in the incidence of European hares in the owl's diet may be attributed to increased abundance of hares in the 10 years elapsed between the two studies. However, J. Rau (personal communication) has unpublished data showing that hares have not clearly increased over the years, and he thinks that reduced abundance of native rodents such as Reithrodon physodes Olfers 1818 may better explain the shift of Magellan horned owls toward European hares-an alternative prey. Residence: confirmed year-round resident (see also Couve \& Vidal 1999 and Matus \& Barría 1999). Other observations: we saw two active nests on top of Nothofagus sp. trees at an ecotone between forest and grassland near the Administración; we have seen this owl perching on cliffs between Portería and Laguna Amarga, and also near Laguna Lazo. Conservation Status in Magallanes: of no conservation concern at present, because of increased favorable habitat (edge between forest and open country) and increased prey availability in the form of European hares (Jaksic \& Jiménez 1986a). Conservation Status in Chile: not listed as threatened by either Glade (1988) or by Rottmann \& López-Callejas (1992).

Austral pygmy owl (Glaucidium nanum King 1828, Strigidae)

Weight: AM 73 g, AM 73 g, AF 62 g, AF 83 g (Humphrey et al. 1970); M 55 g, F 71 g, F 75 g (C.
Venegas, personal communication). Habitat: forest and woodland, in flat or rolling terrain. Diet: Humphrey et al. (1970) reported small birds and small rodents as prey in Tierra del Fuego. Residence: confirmed partial migrant. Couve \& Vidal (1999) and Matus \& Barría (1999) consider it as a year-round resident. Other observations: one of us (J. Jiménez) has seen this small owl twice, once in the Administración area, another close to the Paine Towers. This owl may be more abundant at the Park than suggested by these few sightings. Conservation Status in Magallanes: unknown (Jaksic \& Jiménez 1986a). According to F. Vuilleumier (personal communication), this species is not common, and localized, in Magallanes. Conservation Status in Chile: not listed as threatened by either Glade (1988) or by Rottmann \& López-Callejas (1992).

\section{Short-eared owl (Asio flammeus Pontoppidan 1763, Strigidae)}

Weight: AM 425 g (Humphrey et al. 1970); M 450 g (C. Venegas, personal communication). Habitat: open country close to marshes, in flat or rolling terrain. Diet: it should not differ markedly from that reported by Rau et al. (1992) and by Martínez et al. (1998) near Osorno and Valdivia, i.e., consisting chiefly of rodents. Residence: confirmed breeding migrant or partial migrant. Matus \& Barría (1999) consider it as a likely resident, Guineo (1999) lists it as present, whereas Couve \& Vidal (1999) do not list this species as present in the Park. Other observations: although we did not see this bird, One of us (J. Jiménez) collected three pellets with typical owl features (high bone/fur ratio) at the marsh near the Portería, that contained unidentified rodents. Conservation Status in Magallanes: of no conservation concern at present (Jaksic \& Jiménez 1986a). Conservation Status in Chile: insufficiently known according to both Glade (1988) and Rottmann \& López-Callejas (1992).

Rufous-legged owl (Strix rufipes King 1828, Strigidae)

Weight: 380-420 (D. R. Martínez, personal communication). Habitat: forest, in flat or rolling terrain. Diet: it should not differ markedly from that observed by Martínez \& Jaksic $(1996,1997)$ near Valdivia and Chiloé, i.e., consisting of rodents and insects. Residence: confirmed year-round resident. Matus \& Barría (1999) consider it as a likely resident, and Guineo (1999) lists it as present, but 
Couve \& Vidal (1999) do not list this species as present in the Park. Observations: although we did not see these birds, we heard their calls near Lago Grey and near the Paine Towers. Conservation Status in Magallanes: threatened by reduction of preferred habitat for breeding and feeding, i.e., old-growth forests (Jaksic \& Jiménez 1986a). Conservation Status in Chile: insufficiently known according to Glade (1988), and vulnerable according to Rottmann \& López-Callejas (1992).

\section{RAPTOR SPECIES RICHNESS}

The richness of raptor species in the Park is remarkably high by Chilean, American, and European standards (Table 1, Jaksic et al. 1990, Marti et al. 1993, Jaksic 1998). When considering permanent resident species only, Torres del Paine exceeds in raptor richness four other relatively well studied sites in Chile: Río Clarillo National Reserve (Díaz et al. 2002) and San Carlos de
Apoquindo, both mediterranean-climate evergreen scrub sites near Santiago (Jaksic \& Delibes 1987, Jaksic 2001, Jaksic et al. 2001), Las Chinchillas National Reserve at Aucó, a semi-arid thorn scrub site near Illapel (Jaksic et al. 1992, 1996), and Fray Jorge National Park, a semi-arid thorn scrub site with a milder climate than Aucó, near La Serena (Jaksic et al. 1993, 1997). It should be noted, though, that Torres del Paine is over an order of magnitude larger (241,241 ha) than Río Clarillo National Reserve (10,185 ha), San Carlos de Apoquindo (835 ha), Las Chinchillas National Reserve (4,229 ha), and Fray Jorge National Park (9,959 ha).

In addition to larger size, greater habitat heterogeneity may account for the more diverse raptor fauna at Torres del Paine: the presence of marshes clearly permits the residency of cinereous harriers and short-eared owls, and dense forest stands allow the presence of bicolored hawks and rufouslegged owls. Further, there is a geographic factor involved as well, because of the extremely south-

TABLE 1

Richness in species of raptors in four sites of Chile. See text for definition of resident status and for geographic location of the sites; $(+)=$ permanent presence, $(-)=$ absence, $(?)=$ presence suspected, $( \pm)=$ occasional presence. Localities are arranged from south (left) to north (right)

Riqueza de especies de rapaces en cuatro sitios de Chile. Véase el texto para la definición del estatus de residencia y para localización geográfica de los sitios; $(+)=$ presencia permanente, $(-)=$ ausencia, $($ ? $)=$ presencia presunta, $( \pm)=$ presencia ocasional. Localidades dispuestas de sur (izquierda) a norte (derecha)

\begin{tabular}{|c|c|c|c|c|c|}
\hline Raptor species & $\begin{array}{l}\text { Torres } \\
\text { Paine }\end{array}$ & $\begin{array}{c}\text { Río } \\
\text { Clarillo }\end{array}$ & $\begin{array}{c}\text { San } \\
\text { Carlos }\end{array}$ & Aucó & $\begin{array}{l}\text { Fray } \\
\text { Jorge }\end{array}$ \\
\hline Andean condor (Vultur gryphus) & + & + & + & + & - \\
\hline Turkey vulture (Cathartes aura) & - & + & \pm & - & - \\
\hline Bicolored hawk (Accipiter bicolor) & + & - & \pm & - & - \\
\hline Black-chested eagle (Geranoaetus melanoleucus) & + & + & + & + & + \\
\hline White-throated hawk (Buteo albigula) & - & - & + & - & - \\
\hline Red-backed hawk (Buteo polyosoma) & + & + & + & + & + \\
\hline Rufous-tailed hawk (Buteo ventralis) & $?$ & - & - & - & - \\
\hline Harris' hawk (Parabuteo unicinctus) & - & + & + & + & + \\
\hline Cinereous harrier (Circus cinereus) & + & \pm & \pm & - & \pm \\
\hline White-tailed kite (Elanus leucurus) & - & + & \pm & - & \pm \\
\hline Chimango caracara (Milvago chimango) & + & + & + & \pm & + \\
\hline White-throated caracara (Phalcoboenus albogularis) & + & & - & - & - \\
\hline Andean caracara (Phalcoboenus megalopterus) & - & + & + & - & - \\
\hline Crested caracara (Polyborus plancus) & + & - & - & - & - \\
\hline Peregrine falcon (Falco peregrinus) & + & + & + & - & \pm \\
\hline Aplomado falcon (Falco femoralis) & $?$ & - & \pm & + & \pm \\
\hline American kestrel (Falco sparverius) & + & + & + & + & + \\
\hline Common barn owl (Tyto alba) & + & + & + & + & + \\
\hline Magellan horned owl (Bubo magellanicus) & + & + & + & + & + \\
\hline Austral pygmy owl (Glaucidium nanum) & + & + & + & + & + \\
\hline Burrowing owl (Athene cunicularia) & - & - & + & + & + \\
\hline Short-eared owl (Asio flammeus) & + & - & \pm & - & - \\
\hline Rufous-legged owl (Strix rufipes) & + & + & - & - & - \\
\hline Total resident raptors & $15(17 ?)$ & $14(15 ?)$ & $13(19 ?)$ & $10(11 ?)$ & $9(13 ?)$ \\
\hline
\end{tabular}


erly location of Torres del Paine. The absence of raptors that are characteristic of central and northern Chile, such as Harris' hawk (Parabuteo unicinctus Temminck 1824) and white-tailed kite (Elanus leucurus Vieillot 1818) is related to their more northerly distribution centers. The Harris' hawk does not occur farther south than $44^{\circ} \mathrm{S}$, and the black-shouldered kite does not occur farther south than $42^{\circ} \mathrm{S}$ (Jaksic \& Jiménez 1986a, see also Venegas \& Drouilly 1972).

On the other hand, rufous-tailed hawks and white-throated caracaras have their main distribution area in the southern part of Chile, the rufous-tailed hawk not reaching farther north than $36^{\circ} \mathrm{S}$, and the white-throated caracara, $44^{\circ} \mathrm{S}$ (Jaksic \& Jiménez 1986a). This distributional fact accounts for their absence in the central and northern study areas. Similarly, although crested caracaras are distributed over an extensive latitudinal range in Chile, they are nowhere abundant except in the southern part of the country (Jaksic \& Jiménez 1986a). Conversely, although burrowing owls (Athene cunicularia Molina 1782) are also extensively distributed in Chile, they appear to have been extirpated from Magallanes in historical times. According to Humphrey et al. (1970: 240-241), the disappearance of this owl from Tierra del Fuego around 1920 was "somehow related to the increase in numbers of sheep and other livestock..." Apparently, sheep trampled out the preferred prey of these owls (Magellan tuco-tuco), as well as their burrows. Some authorities have been entertaining the idea of reintroducing this owl to its former range, now that livestock activities are less intense than in the past (Venegas \& Sielfeld 1998: 72).

Finally, it is worth noting that Johnson et al. (1990), when discussing the high mammalian species richness of the area where Torres del Paine is located, stated: "In conclusion, there are two major reasons why the northern Chilean Patagonia has a high diversity of mammalian fauna and is the home of 38 species of mammals. First, is the great variety of habitat types, and second, because the zone serves as a link between two distinctive biotas, the flat and dry Patagonian steppe on the Argentine side, and the wet, Nothofagus forest of the southern Chilean archipelago region." We tend to agree with this conclusion, although emphasizing the first reason over the second.

\section{RAPTOR MACRONICHES}

By macroniches we refer to how raptors are distributed along three niche dimensions: time, habitat, and prey. Of the 17 raptor species probably present in Torres del Paine (Table 1), 14 are diurnal, a figure that includes all Falconiforms and two owls that are quite active in daylight (short-eared owl and austral pygmy owl). In addition, Magellan horned owls are also sometimes active in daylight. The only strictly nocturnal raptors at the Park are common barn owls and rufous-legged owls.

Only four raptor species seem to be forestdwellers: bicolored Hawks, rufous-tailed hawks, austral pygmy owls, and rufous-legged owls (Table 2). All of these species are seen regularly in woodlands, along the ecotones between the forest and open country. The remaining 13 species are edge or open-country dwellers. Iriarte et al. (1990) sampled small mammals in scrub and forest habitats of the Park, and found that trapping success was only slightly higher in scrub $\left(0.63\right.$ captures trap-night $\left.^{-1}\right)$ than in forest $(0.52)$. Indeed, trapping success was very low (only 0.06) in the most open sites: grasslands. Obviously, the numerical abundance of small mammals does not explain why most raptors hunt in open country. Perhaps an explanation is that even though smallmammal abundance is similar between forest and scrub, the vulnerability of small mammals is higher in the more open country (and thus the hunting success of the raptors). Of course, the two raptors that prey most extensively on European hares, black-chested eagles and Magellan horned owls, find this prey in high abundance only in open country (Iriarte et al. 1990).

Out of the nine major prey resources recognized in the Park, only one (amphibians) was not exploited at all. At least two anuran species occur in the Park (Markham 1971), the terrestrial toad Bufo variegatus Gunther 1870 and the aquatic frog Pleurodema bufonina Bell 1843. The frog may be inaccessible for raptors, but the toad should not be. However, Chilean raptors are known to prey on toads only rarely. Of eight raptor species whose diets were studied in San Carlos de Apoquindo (Jaksic et al. 1981), only one, the burrowing owl, consumed anurans and did so to a very small extent ( $3 \%$ of its prey by number). In Aucó (Jaksic et al. 1992), out of eight raptor species studied, only burrowing owls ate anurans to any extent (1-9\% of its prey). And in Fray Jorge (Jaksic et al. 1993), out of seven raptor species monitored for food habits, again only the burrowing owl took anurans as prey (0-13\%). It is tempting to speculate that if burrowing owls were present at Torres del Paine, they might be exploiting this "unused" prey resource.

The remaining eight prey resources present at the Park are probably exploited by one (only peregrine falcons may be able to exploit medium- 
sized birds) to nine raptor species (small-sized mammals). High concentration of raptor predation on small- and medium-sized mammals has also been reported in the central and northern Chilean studies referred to above.

Torres del Paine has more scavenging raptors than reported in other studies in Chile (Jaksic \& Jiménez 1986b), but a similar number to that reported for Argentine Patagonia (Travaini et al. 1998). In the lowlands of central and northern Chile, only chimango caracaras play a major scavenging role. In none of these sites are there many large mammals (native or introduced) such as guanacos or sheep, and even medium-sized mammals such as European hares are not as common as in Torres del Paine (Engh et al. 1997). Perhaps the low availability of carrion in those sites is insufficient to maintain a higher diversity of scavengers. Indeed, Simonetti et al. (1984) reported high rates of disappearances of rodent carcasses in San Carlos de Apoquindo, and noted that in addition to local predators, ants (Camponotus spp.), carrion beetles (Trox bullatus), mouse opossums (Thylamys elegans Waterhouse 1838, Didelphidae), and Chilean racerunners (Callopistes palluma Molina 1782, Teiidae) may have disposed of carcasses quickly.

\section{RAPTOR NICHE RELATIONSHIPS}

Niche relationships refer to the way raptors couse one or more niche dimensions. Ideally, a study of niche relationships should include quantification of time, habitat, and prey use by sympatric raptors. However, Jaksic et al. (1981) argued that when different raptor species use the same hunting habitat, independently of their activity times, their food-niche relationships are the only important aspect to be taken into account. This is

TABLE 2

Major food resources recognized, and where sought, by raptors in Torres del Paine. Scientific names of raptor species are in Table 1

Recursos alimentarios reconocidos, y dónde son buscados, por las rapaces en Torres del Paine. Los nombres científicos de las especies de rapaces están en la Tabla 1

\begin{tabular}{|c|c|c|}
\hline Food resource & In forest & In open country \\
\hline (1) Medium-sized mammals (hares, carnivores) & None & $\begin{array}{l}\text { Black-chested eagle } \\
\text { Magellan horned owl }\end{array}$ \\
\hline (2) Small-sized mammals (rodents) & $\begin{array}{l}\text { Rufous-tailed hawk } \\
\text { Austral pygmy owl } \\
\text { Rufous-legged owl }\end{array}$ & $\begin{array}{l}\text { Red-backed hawk } \\
\text { Cinereous harrier } \\
\text { American kestrel } \\
\text { Common barn owl } \\
\text { Magellan horned owl } \\
\text { Short-eared owl }\end{array}$ \\
\hline (3) Medium-sized birds (ducks, ibises) & None & Peregrine falcon \\
\hline (4) Small-sized birds (songbirds, doves) & $\begin{array}{l}\text { Bicolored hawk } \\
\text { Austral pygmy owl }\end{array}$ & $\begin{array}{l}\text { Aplomado falcon } \\
\text { Cinereous harrier } \\
\text { Peregrine falcon } \\
\text { American kestrel }\end{array}$ \\
\hline (5) Reptiles (lizards) & None & $\begin{array}{l}\text { Cinereous harrier } \\
\text { American kestrel }\end{array}$ \\
\hline (6) Amphibians (toads, frogs) & None & None \\
\hline (7) Arthropods (insects, spiders) & Austral pygmy owl & $\begin{array}{l}\text { Aplomado falcon } \\
\text { Cinereous harrier } \\
\text { Chimango caracara } \\
\text { American kestrel }\end{array}$ \\
\hline (8) Oligochaetes (earthworms) & None & $\begin{array}{l}\text { Chimango caracara } \\
\text { White-throated caracara }\end{array}$ \\
\hline (9) Carrion & None & $\begin{array}{l}\text { Andean condor } \\
\text { Chimango caracara } \\
\text { Crested caracara } \\
\text { White-throated caracara }\end{array}$ \\
\hline
\end{tabular}


what Iriarte et al. (1990) did in their dietary analyses of four broadly sympatric raptor species in Torres del Paine: black-chested eagle, cinereous harrier, common barn owl, and Magellan horned owl.

Although these four species represent only half the number of raptor species that hunt for medium- and small-sized mammals in open country at the Park (Table 2), the study of Iriarte et al. (1990) contributed important insights on how mammal-eating raptors may interact with each other. Using a measurement of diet similarity, Iriarte et al. (1990) found that cinereous harriers were the most divergent raptors in the use of prey resources. Diet similarity with black-chested eagles, Magellan horned owls, and common barn owls was 31,52 , and $50 \%$, respectively. These figures are low compared to central Chilean studies (Jaksic et al. 1981, Jaksic \& Delibes 1987). The apparent reason is that cinereous harriers are relatively small in body mass (mean $=398 \mathrm{~g}, \mathrm{n}=$ 9) and are omnivorous hunters, eating not only small mammals but also birds, lizards, insects, and arachnids. There is also some degree of habitat separation between this harrier and the remaining three raptor species, because the harrier forages mostly near marshes.

Black-chested eagles in turn have low diet similarity with Magellan horned owls and common barn owls (51 and $5 \%$, respectively). This is because eagles appear to feed almost exclusively on European hares (over $91 \%$ of their diet by numbers, even higher by biomass). The large body mass (mean $=2,568 \mathrm{~g}, \mathrm{n}=7$ ) and large size of the talons of these eagles may facilitate their killing of the relatively large hare (over 2,000 g).

The species with the most similar diets were the Magellan horned and common barn owls (82\% similarity), a percentage about twice as large as that reported for central Chile (Jaksic et al. 1981, Jaksic \& Delibes 1987). Their diets were similar even to the point of relative incidences of prey, and differed only because Magellan horned owls preyed on hares. This finding is not surprising, as in central Chile Jaksic \& Yáñez (1980) observed the same divergence between these two owls in their use of the relatively large European rabbit (Oryctolagus cuniculus Linnaeus 1758, 1,300 g). The larger body mass $(1,091 \mathrm{~g}, \mathrm{n}=4)$ and talons of Magellan horned owls compared to common barn owls ( $310 \mathrm{~g}, \mathrm{n}=5)$ may account for this only difference in prey composition in the Park.

In summary, the relatively large European hare appears with higher frequency in raptors' diets according to their increasing size, from common barn owls and cinereous harriers, through Magellan horned owls to black-chested eagles.
The former two species do not prey on hares at all, the third preys on them to some extent, and the latter to a large extent. One is left wondering what were the food-niche relationships among these three species before European hares were introduced (Novaro et al. 2000).

\section{CONCLUSIONS}

Torres del Paine harbors a remarkably high number of raptor species. It is unfortunate that local raptor populations have not been consistently monitored during the Park recovery from extensive clearing and overgrazing, while at the same time being invaded by European hares and witnessing a remarkable recovery of its guanaco stocks. These "natural experiments" must have left a mark on the ecology of raptors present at the Park. It is not too late, though, to think about the future changes that Torres del Paine will undergo, by the action of natural or human agents, expected or unexpected.

We propose that a monitoring program be started, focusing on several features of the raptors' life histories: (a) residence status and population trends (including breeding success, migratory movements, and mortality patterns); (b) habitat use; (c) presumable effects of human disturbances (fires, tourism); (d) food habits as related to prey abundances in different habitat types; and (e) interrelationships among the raptor species (including, but not limited to, competitive and agonistic interactions).

The raptor monitoring should be based on a stratified survey method using transects (Fuller \& Mosher 1981, 1987). Transects should be of a standard width (determined by a pilot study), stratified by habitat and proportional in length to the amount of the three main habitats recognized in the Park: deciduous forests, woodlands, and open terrain. Monitoring should be conducted using the same transects along established dirt roads and/or trails once a year, both during breeding and non-breeding seasons. During the former season raptors are more conspicuous because of their breeding behavior and vocalizations, and during the latter because of the better visibility afforded when deciduous trees shed their leaves. Surveys should be conducted preferably by the same park rangers or observers familiar with the species, their vocalizations, and the terrain. Observers should move on foot or on horseback along the transects at a relatively constant speed, and record each individual raptor observed (flying or perched) or heard within the standard width. This protocol, when standardized by the effort 
used (e.g., km surveyed), will provide a means of comparison of relative abundance by species, habitat, season, and year, and may as well be conducted while performing other activities, such as guanaco counts or patrolling the Park.

This monitoring program could be easily implemented and is cost-effective. The Program of Sponsored Research in the System of Protected Areas, launched by Chile's Corporación Nacional Forestal several years ago, should consider rating this proposed program as a high priority, and perhaps even actively encourage researchers into starting it.

\section{ACKNOWLEDGMENTS}

We are grateful to Bill Franklin and Warren Johnson for encouraging us to write this paper. We thank David R. Martínez, Jaime Rau, Claudio Venegas, and Francois Vuilleumier for reviewing an earlier draft, and sharing with us their expertise on Patagonian raptors. We are indebted to two anonymous reviewers that made cogent criticisms of our paper, and contributed to improve it. Yerko Vilina supplied us with some difficult to obtain literature. This research was funded by grant FONDAP-FONDECYT 1501-0001 to the Center for Advanced Studies in Ecology \& Biodiversity.

\section{LITERATURE CITED}

ARAYA B, M BERNAL, R SCHLATTER \& $M$ SALLABERRY (1995) Lista patrón de las aves chilenas. Tercera edición. Editorial Universitaria, Santiago, Chile. 35 pp.

COUVE E \& C VIDAL (1999) Dónde observar aves en el Parque Nacional Torres del Paine: Guía de identificación. Editorial Fantástico Sur - Birding \& Nature Tours, Punta Arenas, Chile. 238 pp.

DEL HOYO J, A ELLIOTT \& J SARGATAL (eds) (1994) Handbook of the birds of the world. Vol. 2: New World Vultures to Guineafowl. Lynx Editions, Barcelona, Spain. 638 pp.

DEL HOYO J, A ELLIOTT \& J SARGATAL (eds) (1999) Handbook of the birds of the world. Vol. 5: Barn Owls to Hummingbirds. Lynx Editions, Barcelona, Spain. $759 \mathrm{pp}$.

DÍAZ IA, C SARMIENTO, L ULLOA, R MOREIRA, R NAVIA, E VELIZ \& C PEÑA (2002) Vertebrados terrestres de la Reserva Nacional Río Clarillo, Chile central: representatividad y conservación. Revista Chilena de Historia Natural 75: 433-448.

ELLIS DH \& C PÉRES-GARAT (1983) The pallid falcon Falco kreyenborgi is a color phase of the austral peregrine falcon (Falco peregrinus cassini). Auk 100: 269-271.
ENGH AL, WL FRANKLIN \& RJ SARNO (1997) Breeding biology and food habits of the Andean crested caracara (Polyborus plancus) in the Patagonia of southern Chile. Vida Silvestre Neotropical 6: 48-52.

FULLER MR \& JA MOSHER (1981) Methods of detecting and counting raptors: a review. In: Ralph CJ \& JM Scott (eds) Estimating numbers of terrestrial birds: 235-246. Studies in Avian Biology No. 6. $x+630$ pp.

FULLER MR \& JA MOSHER (1987) Raptor survey techniques. In: Giron-Pendleton BA, BA Millsap, KW Cline \& BM Bird (eds) Raptor management techniques manual: 37-65. National Wildlife federation, Washington, District of Columbia. xiii $+420 \mathrm{pp}$.

GARAY G \& O GUINEO (1991) Conociendo Torres del Paine. Talleres Don Bosco, Punta Arenas, Chile. 110 pp.

GARAY G \& O GUINEO (1993) Fauna, flora y montaña: Torres del Paine. Talleres Don Bosco, Punta Arenas, Chile. 144 pp.

GLADE A (ed) (1988) Libro rojo de los vertebrados terrestres chilenos. Corporación Nacional Forestal, Ministerio de Agricultura, Santiago, Chile. 65 pp.

GRIGERA DE \& EH RAPPOPORT (1983) Status and distribution of the European hare in South America. Journal of Mammalogy 64: 163-166.

GUINEO O (1999) Fauna de Magallanes en peligro. Talleres Don Bosco, Punta Arenas, Chile. 86 pp.

HIRALDO FJ, A DONÁZAR, O CEBALLOS, A TRAVAINI, J BUSTAMANTE \& M FUNES (1995) Breeding biology of a grey eagle-buzzard population in Patagonia. Wilson Bulletin 107: 675-685.

HUMPHREY PS, D BRIDGE, PW REYNOLDS \& RT PETERSON (1970) Birds of Isla Grande (Tierra del Fuego). Preliminary Smithsonian Manual, Museum of Natural History, University of Kansas, Lawrence, Kansas. 411 pp.

IRIARTE JA, WL FRANKLIN \& WE JOHNSON (1990) Diets of sympatric raptors in southern Chile. Journal of Raptor Research 24: 41-46.

JAKSIC FM (1998) Ecología de los vertebrados de Chile. Segunda edición. Ediciones Universidad Católica de Chile, Santiago, Chile. 262 pp.

JAKSIC FM (2001) Spatiotemporal variation patterns of plants and animals in San Carlos de Apoquindo, central Chile. Revista Chilena de Historia Natural 74: 477-502.

JAKSIC FM \& M DELIBES (1987) A comparative analysis of food-niche relationships and trophic guild structure in two assemblages of vertebrate predators differing in species richness: causes, correlations, and consequences. Oecologia 71: 461-472.

JAKSIC FM \& JE JIMÉNEZ (1986a) The conservation status of raptors in Chile. Birds of Prey Bulletin 3: 95-104.

JAKSIC FM \& JE JIMÉNEZ (1986b) Trophic structure and food-niche relationships of Nearctic and Neotropical raptors: an inferential approach. Proceedings of the XIX International Ornithological Congress (Ottawa, Ontario, Canada) 2: 2337-2349.

JAKSIC FM \& K SCHWENK (1983) Natural history observations on Liolaemus magellanicus, the southernmost lizard in the world. Herpetologica 39: 457-461. 
JAKSIC FM \& JL YÁÑEZ (1980) Differential utilization of prey resources by great horned owls and barn owls in central Chile. Auk 97: 895-896.

JAKSIC FM, J RAU \& J YÁÑEZ (1978) Oferta de presas y predación por Bubo virginianus (Strigidae) en el Parque Nacional "Torres del Paine". Anales del Instituto de la Patagonia (Chile) 9: 199-202.

JAKSIC FM \& HW GREENE \& JL YÁÑEZ (1981) The guild structure of a community of predatory vertebrates in central Chile. Oecologia 49: 21-28.

JAKSIC FM, JL YÁÑEZ \& JR RAU (1986) Prey and trophic ecology of great horned owls in western South America: an indication of latitudinal trends. Journal of Raptor Research 20: 113-116.

JAKSIC FM, JE JIMÉNEZ \& P FEINSINGER (1990) Dynamics of guild structure among avian predators: competition or opportunism? Proceedings of the XX International Ornithological Congress (Christchurch, New Zealand) 3: 1480-1488.

JAKSIC FM, JE JIMÉNEZ, SA CASTRO \& P FEINSINGER (1992) Numerical and functional response of predators to a long-term decline in mammalian prey at a semi-arid Neotropical site. Oecologia 89: 90-101.

JAKSIC FM, PL MESERVE, JR GUTIÉRREZ \& E TABILO (1993) The components of predation on small mammals in semiarid Chile: preliminary results. Revista Chilena de Historia Natural 66: 305-321.

JAKSIC FM, P FEINSINGER \& JE JIMÉNEZ (1996) Ecological redundancy and long-term dynamics of vertebrate predators in semiarid Chile. Conservation Biology 10: 252-262.

JAKSIC FM, SI SILVA, PL MESERVE \& JR GUTIÉRREZ (1997) A long-term study of vertebrate predator responses to an El Niño (ENSO) disturbance in western South America. Oikos 78: 341-354.

JAKSIC FM, EF PAVEZ, JE JIMÉNEZ \& JC TORRESMURA (2001) The conservation status of raptors in the Metropolitan Region, Chile. Journal of Raptor Research 35: 151-158.

JIMÉNEZ JE (1993) Notes on the diet of the Aplomado Falcon (Falco femoralis) in northcentral Chile. Journal of Raptor Research 27: 161-163.

JIMÉNEZ JE (1995) Historia natural del aguilucho común Buteo polyosoma: una revisión. Hornero (Argentina) 14: 1-8.

JIMÉNEZ JE \& FM JAKSIC (1988) Ecology and behavior of southern South American Cinereous Harriers, Circus cinereus. Revista Chilena de Historia Natural 61: 199-208.

JIMÉNEZ JE \& FM JAKSIC (1989) Behavioral ecology of grey eagle-buzzards, Geranoaetus melanoleucus, in central Chile. Condor 91: 913-921.

JIMÉNEZ JE \& FM JAKSIC (1990) Historia natural del águila Geranoaetus melanoleucus: una revisión. Hornero (Argentina) 13: 97-110.

JOHNSON AW (1965) The birds of Chile and adjacent regions of Argentina, Bolivia and Peru. Platt Establecimientos Gráficos, Buenos Aires, Argentina. Volume I, $398 \mathrm{pp}$.

JOHNSON AW (1967) The birds of Chile and adjacent regions of Argentina, Bolivia and Peru. Platt Establecimientos Gráficos, Buenos Aires, Argentina. Volume II. 447 pp.
JOHNSON WE, WL FRANKLIN \& JA IRIARTE (1990) The mammalian fauna of the northern Chilean Patagonia: a biogeographical dilemma. Mammalia 54: 457-469.

MARKHAM BJ (1971) Catálogo de los anfibios, reptiles, aves y mamíferos de la provincia de Magallanes (Chile). Publicaciones del Instituto de la Patagonia (Chile), Serie Monografías 1: 1-64.

MARTI CD, E KORPIMÄKI \& FM JAKSIC (1993) Trophic structure of raptor communities: a three-continent comparison and synthesis. In: Power DM (ed) Current Ornithology 10: 47-137. Plenum Publishing Corporation, New York, New York. xiv +383 pp.

MARTÍNEZ DR \& FM JAKSIC (1996) Habitat, abundance, and diet of rufous-legged owls (Strix_rufipes) in temperate forest remnants of southern Chile. Ecoscience 3: 259-263.

MARTÍNEZ DR \& FM JAKSIC (1997) Selective predation on scansorial and arboreal mammals by rufouslegged owls (Strix rufipes) in southern Chilean rainforest. Journal of Raptor Research 31: 370-375.

MARTÍNEZ DR, RA FIGUEROA, CL OCAMPO \& FM JAKSIC (1998) Food habits and hunting ranges of short-eared owls (Asioflammeus) in agricultural landscapes of southern Chile. Journal of Raptor Research 32: 111-115.

MATUS R \& C BARRÍA (1999) Adiciones a la lista de aves del Parque Nacional Torres del Paine. Anales del Instituto de la Patagonia (Chile) 27: 105-113.

MCNUTT JW (1981) Selección de presa y comportamiento de caza del halcón peregrino (Falco peregrinus) en Magallanes y Tierra del Fuego. Anales del Instituto de la Patagonia (Chile) 12: 221-228.

MCNUTT JW (1984) A peregrine falcon polymorph: observations on the reproductive behavior of Falco kreyenborgi. Condor 86: 378-382.

MENDELHALL VM \& LF PANK (1980) Secondary poisoning of owls by anticoagulant rodenticides. Wildlife Society Bulletin 8: 311-315.

NOVARO AJ, MC FUNES \& RS WALKER (2000) Ecological extinction of native prey of a carnivore assemblage in Argentine Patagonia. Biological Conservation 92: 25-33.

NÚÑEZ H \& F JAKSIC (1992) Lista comentada de los reptiles terrestres de Chile continental. Boletín del Museo Nacional de Historia Natural (Chile) 43: 6391.

PISANO E (1974) Estudio ecológico de la región continental sur del área andino-patagónica. II: Contribución a la fitogeografía de la zona del Parque Nacional "Torres del Paine". Anales del Instituto de la Patagonia (Chile) 5: 59-104.

RAU JR \& J YÁÑEZ (1981) Nuevos antecedentes sobre la alimentación de Bubo_virginianus Vieillot, 1817 en Magallanes. Noticiario Mensual del Museo Nacional de Historia Natural (Chile) 295: 9-10.

RAU JR, J YÁÑEZ \& FM JAKSIC (1978) Confirmación de Notiomys macronyx alleni O. y Eligmodontia typus typus C., y primer registro de Akodon (Abrothrix) lanosus T. (Rodentia: Cricetidae) en la zona de Ultima Esperanza (XII Región, Magallanes). Anales del Instituto de la Patagonia (Chile) 9: 203-204. 
RAU JR, MC VILLAGRA, ML MORA, DR MARTÍNEZ \& MS TILLERÍA (1992) Food habits of the shorteared Owl (Asioflammeus) in southern South America. Journal of Raptor Research 26: 35-36.

ROTTMANN J \& MV LÓPEZ-CALLEJAS (1992) Estrategia nacional de conservación de aves. Servicio Agrícola y Ganadero, División de Protección de los Recursos Naturales Renovables, Serie Técnica 1: 116.

SARNO RJ, WL FRANKLIN \& WS PREXL (2000) Activity and population characteristics of Andean condors in southern Chile. Revista Chilena de Historia Natural 73: 3-8.

SIMONETTI JA, JL YÁÑEZ \& ER FUENTES (1984) Efficiency of rodent scavengers in central Chile. Mammalia 48: 608-609.

TAMAYO M, H NÚÑ̃E \& J YÁÑEZ (1987) Lista sistemática actualizada de los mamíferos vivientes en Chile y sus nombres comunes. Noticiario Mensual del Museo Nacional de Historia Natural (Chile) 312: 113.

TOWNSEND MG, MR FLETCHER, EM ODAM \& PI STANLEY (1981) An assessment of the secondary poisoning hazard of Warfarin to tawny owls. Journal of Wildlife Management 45: 242-248.

TRAVAINI A, JA DONÁZAR, A RODRÍGUEZ, O CEBALLOS, M FUNES, M DELIBES \& F HIRALDO (1998) Use of European hare (Lepus europaeus) carcass by an avian scavenging assemblage in Patagonia. Journal of Zoology (London) 246: 175-181.

VELOSO A \& J NAVARRO (1988) Lista sistemática y distribución geográfica de anfibios y reptiles de Chile. Bollettino del Museo Regionale di Scienze Naturali, Torino (Italia) 6: 481-539.

Associate Editor: P. Ojeda

Received November 14, 2001; accepted February 28, 2002
VENEGAS C (1982) Suplemento a la guía de campo de las aves de Magallanes. Anales del Instituto de la Patagonia (Chile) 13: 189-206.

VENEGAS C \& P DROUILLY (1972) Nota aclaratoria acerca de la presencia de Parabuteo unicinctus unicinctus (Temminck) en Magallanes. Anales del Instituto de la Patagonia (Chile) 3: 201-202.

VENEGAS C \& J JORY (1979) Guía de campo para las aves de Magallanes. Publicaciones del Instituto de la Patagonia (Chile), Serie Monografías 11: 1-253.

VENEGAS C \& W SIELFELD (1998) Catálogo de los vertebrados de la Región de Magallanes y Antártica Chilena. Ediciones de la Universidad de Magallanes, Punta Arenas, Chile. 122 pp.

VUILLEUMIER F (1985) Forest birds of Patagonia: ecological geography, speciation, endemism, and faunal history. In: Buckley PA, MS Foster, ES Morton, RS Ridgely \& FG Buckley (eds) Neotropical ornithology: 255-304. Ornithological Monographs 36. Plenum Publishing Corporation, New York, New York. xii +1041 pp.

VUILLEUMIER F (1997) An overview of field guides to neotropical birds with remarks on their role in the development of neotropical ornithology. Ornitología Neotropical 8: 195-236.

YÁÑEZ J, J RAU \& FM JAKSIC (1978) Estudio comparativo de la alimentación de Bubo virginianus (Strigidae) en dos regiones de Chile. Anales del Museo de Historia Natural de Valparaíso (Chile) 11:97-104. 